\title{
Socijalni doprinosi službenika Europske unije
}

\section{Ivana Božac *}

$\begin{array}{ll}\text { UDK } & 336.027 .5: 35.08(4) \mathrm{EU} \\ & 368.042: 35.08(4) \mathrm{EU} \\ & 368.914: 35.08(4) \mathrm{EU} \\ & 349.232: 35.08(4) \mathrm{EU} \\ & 10.31297 / \mathrm{hkju} .18 .4 .6 \\ \text { DOI } & 23.10 .2017 . \\ \text { Review scientific paper / pregledni znanstveni rad } \\ \text { Primljeno: } & 16.3 .2018 .\end{array}$

Sud Europske unije odlučivao je o predmetu u kojem se postavilo pitanje primjenjivosti nacionalnih propisa kojima se obveza neizravnog financiranja domaćeg sustava socijalnog osiguranja nameće poreznim rezidentima države članice koji su obveznici sustava socijalnog osiguranja Europske unije. Uz prikaz pravila o koordinaciji sustava socijalne sigurnosti u Uniji i analizu argumentacija kojom se Sud vodio pri davanju odgovora na postavljeno prethodno pitanje, u radu se daje sustavni pregled pravnog uređenja statusa službenika europskih institucija te razmatraju implikacije koje ta pravna pravila imaju za pravne sustave država članica.

Ključne riječi: službenici EU-a, dužnosnici EU-a, obvezno osiguranje u sustavu socijalne sigurnosti institucija EU-a, sudjelovanje u financiranju socijalne sigurnosti države članice, načelo primjene jednog socijalnog zakonodavstva

* Ivana Božac, Head of Unit of the Court of Justice of the European Union, Luxembourg (načelnica odjela u Sudu Europske unije, Luxembourg, e-mail: ivana.bozac@curia. europa.eu). Autorica u članku iznosi svoje vlastite stavove te ni na koji način ne predstavlja službeno stajalište institucije u kojoj je zaposlena.

ORCID ID: 0000-0002-3709-2055 


\section{Uvod}

W. de Lobkowicz umirovljeni je službenik Europske komisije i francuski porezni rezident. Na temelju francuskog Općeg poreznog zakonika dužan je platiti socijalne doprinose na dohodak od nekretnina u Francuskoj. O tom je istom »porezu« Sud Europske unije već imao priliku odlučivati u predmetu de Ruyter te je ocijenio da je riječ o socijalnom doprinosu koji je obuhvaćen pravilima o koordinaciji sustava socijalne sigurnosti država članica Unije i na koji se primjenjuje načelo jednog socijalnog zakonodavstva. Stoga ga G. de Ruyter, francuski porezni rezident koji je socijalno osiguran u Nizozemskoj, nije dužan plaćati. Međutim, W. de Lobkowicz nije socijalno osiguran u nekoj drugoj državi članici, već je osiguran u sustavu socijalnog osiguranja institucija Europske unije. Stoga se u tom predmetu postavilo pitanje bi li nametanje takve obveze osobi koja je već osigurana u sustavu socijalnog osiguranja institucija EU-a bilo u skladu s pravom Unije. Središnje mjesto u ovom radu pripada analizi argumentacije kojom se Sud vodio pri donošenju odluke o tom pitanju. Prije analize presude razmotrit će se pravno uređenje položaja službenika i ostalog osoblja institucija Unije te ukratko izložiti pravila o koordinaciji sustava socijalne sigurnosti u Uniji. Nakon analize presude, sažimlju se zaključci Suda te se razmatra osobitost pravnog statusa službenika Unije i implikacije koje pravne norme koje uređuju taj status imaju za države članice.

Pri analizi naznačenog problema rada treba skrenuti pažnju na terminološki problem koji se pojavljuje u hrvatskom jeziku. Naime, u službenim prijevodima primarnog i sekundarnog zakonodavstva EU-a na hrvatski jezik, za francuski pojam fonctionnaire (official, funzionario, Beamter) koristi se pojam »dužnosnik«, dok se za pojam autres agents (other servants, altri agenti, Bediensteten) koristi »ostali službenici«. Međutim, s obzirom na bitnu sadržajnu razliku između pojmova »službenik« i »dužnosnik« u hrvatskom pravu, a kako bi se izbjegle nedoumice i terminološke nedosljednosti, u ovom tekstu za francuski pojam fonctionnaire koristi se pojam »službenik«, osim kada je riječ o izravnom citatu zakonodavstva, u kojem će slučaju citat biti preuzet u cijelosti uz dodavanje prijevoda u uglatim zagradama [službenik] kad je to potrebno, dok će se za pojam autres agents koristiti »ostalo osoblje« (o ostalim kategorijama osoblja v. infra). ${ }^{1}$

${ }^{1}$ Naime, iako pravo Unije ima svoju vlastitu terminologiju, odnosno pojmovi prava EU-a imaju autonomno značenje, koje ne mora odgovarati značenju u različitim nacionalnim pravnim sustavima (u tom smislu vidjeti, primjerice, presude Suda u predmetima M.K.H. Hoekstra i CILFIT, t. 19.), smatramo da je u ovom slučaju riječ o neodgovarajućem 


\section{Pravni položaj zaposlenika institucija Unije}

\subsection{Javna služba EU-a²}

Još prilikom pokretanja europske integracije postignut je dogovor da institucije raspolažu administracijom koja je neovisna o državama članicama pa je stoga odbačena opcija javne službe EU-a koju bi činili nacionalni službenici upućeni u institucije. Tadašnja promišljanja bila su usmjerena prema dvama drugim rješenjima: zapošljavanje osoblja na temelju ugovora, po uzoru na međunarodne organizacije, ili zapošljavanje službenika čiji je status uređen propisima. U konačnici je prihvaćena potonja opcija, po uzoru na francusku javnu upravu (Feugier \& Pradines, 2015, str. 16; Dalle-Crode, 2008, str. 13).

Razvoj javne službe EU-a neodvojivo je povezan sa samim procesom europske integracije. Tako su prvi pravilnici doneseni 1956., za osoblje Europske zajednice za ugljen i čelik (EZUČ), ${ }^{3}$ te 1961 . dva pravilnika za osoblje

terminološkom odabiru u hrvatskom prijevodu acquisa. Pravilnik o osoblju (v. infra) propis je kojim se uređuju prava i obveze osoba koje su imenovane na stalno radno mjesto u jednoj od institucija na temelju akta koji je izdalo tijelo za imenovanje te institucije (čl. 1a Pravilnika o osoblju, koji definira pojam »dužnosnik«). Dakle, iz samog sadržaja navedenog propisa proizlazi da je riječ o osobama koje su u navedenim institucijama u stalnom radnom odnosu koji je statusnog karaktera, a ne o osobama koje su imenovane na posebna dužnosnička ili rukovodeća mjesta. Naime, u hrvatskom pravu pojam »dužnosnik« obuhvaća osobe koje su imenovane na točno određene visoke dužnosti u tijelima državne vlasti odnosno rukovodeće državne službenike (vidjeti primjerice Zakon o obvezama i pravima državnih dužnosnika i Zakon o sprječavanju sukoba interesa), dok se pojam »službenik odnosi na osobe koje u državnim, lokalnim ili javnim tijelima kao redovito zanimanje obavljaju poslove iz djelokruga tih tijela utvrđene Ustavom, zakonom ili drugim propisima (vidjeti primjerice Zakon o državnim službenicima, Zakon o službenicima i namještenicima u lokalnoj i područnoj (regionalnoj) samoupravi, Zakon o plaćama u javnim službama i Uredbu o nazivima radnih mjesta i koeficijentima složenosti poslova u javnim službama). Sukladno tome, iako u širem smislu, »službenik« može biti jedan od naziva za radnika, osobu koja se zaposlila i radi u radnom odnosu (Pezo, 2007.), za pojam autres agents koristit ćemo »ostalo osoblje« upravo zato što je riječ o ostalim kategorijama zaposlenika institucija, čiji se status razlikuje od statusa službenika, kao stalno zaposlenog osoblja.

${ }^{2} \mathrm{U}$ radu se pojam »europska javna služba« $\mathrm{i}$ »javna služba Unije/EU-a« koriste se kao jednakovrijedni i zamjenjivi, a njima se označavaju općenito zaposlenici institucija EUa. Dakle, navedeni se pojmovi ne odnose na zaposlenike u službi organizacija poput Vijeća Europe. Usto, navedeni se pojmovi koriste za označavanje svih kategorija zaposlenika institucija EU-a (službenika, članova privremenog i ugovornog osoblja) i nisu ograničeni samo na službenike stricto sensu.

${ }^{3}$ Navedeni pravilnik stupio je na snagu 1. srpnja 1956. Njegov čl. 1. sadržava definiciju pojma »nadnacionalni službenici« (fonctionnaires supranationaux), i njime je obilježen početak povijesti javne službe EU-a, neovisne o javnim službama država članica. 
Europske ekonomske zajednice (EEZ) i Europske zajednice za atomsku energiju (Euratom). Nakon stupanja na snagu Ugovora o spajanju, ${ }^{4}$ kojim je određeno da službenici i ostali zaposlenici tih triju zajednica postaju na dan stupanja na snagu tog ugovora službenici i ostali zaposlenici Zajednica i čine dio jedinstvene administracije Zajednica, navedeni pravilnici zamijenjeni su 1968. jedinstvenim Pravilnikom o osoblju. ${ }^{5}$ Tim su Pravilnikom potvrđena glavna obilježja javne službe EU-a utvrđena prethodnim pravilnicima: jedinstvenost (jedan statut za jedinstven korpus službenika u službi svih institucija Zajednica), neovisnost (službenici se u svom radu moraju voditi isključivo općim europskim interesom), stalnost (stalna radna mjesta predviđena sistematizacijom radnih mjesta pojedine institucije popunjavaju se uglavnom karijernim službenicima) i stručnost (tehnički zadaci zahtijevaju visoku razinu stručnosti, povjereno im je obavljanje važnih zadaća) (Feugier \& Pradines, 2015).

Navedeni Pravilnik ostao je dugo neizmijenjen te je razdoblje između 1960-ih i 2000. obilježila stabilnost, ${ }^{6}$ koja je omogućila razvoj javne službe EU i njezin doprinos izgradnji europskog projekta (Feugier \& Pradines, 2015, str. 31).

Nakon tog razdoblja započeo je postupak reformi koje su dovele do velike izmjene Pravilnika 2004., koja je smatrana nužnom kako radi povratka povjerenja građana u institucije tako zbog proširenja Unije na 10 novih država članica (Feugier \& Pradines, 2015, str. 22). Potom su uslijedile manje izmjene koje su bile potrebne iz institucionalnih razloga - 2009. uređen je status parlamentarnih asistenata (Uredba br. 160/2009), a 2010. Pravilnik o osoblju izmijenjen je zbog osnivanja Europske službe za vanjsko djelovanje (ESVD) (Uredba br. 1080/2010). ${ }^{7}$ Konačno, 2013. došlo je do posljednjih značajnijih izmjena, koje su bile posljedica ekonomske krize i smanjenja proračunskih troškova (Uredba br. 1023/2013). Navedene iz-

${ }^{4}$ Ugovor o osnivanju jedinstvenog Vijeća i jedinstvene Komisije Europskih zajednica (SL 1967, 152, str. 2).

${ }^{5}$ Pravilnik o osoblju za dužnosnike [službenike] Europske unije (Pravilnik o osoblju) i Uvjeti zaposlenja ostalih službenika [ostalog osoblja] Europske unije uspostavljeni su Uredbom br. 259/68.

${ }^{6}$ Pravilnik je, doduše, u navedenom razdoblju gotovo stotinu puta izmijenjen uredbama Vijeća, ali su se navedene izmjene odnosile isključivo na prilagodbu primitaka od rada i mirovina službenika i drugih zaposlenika.

${ }^{7} \mathrm{Na}$ temelju te izmjene Pravilnik o osoblju za službenike Europskih zajednica postao je Pravilnik o osoblju za službenike Europske unije. 
mjene omogućile su razvoj i prilagodbu pravnog okvira javne službe EUa, uz očuvanje njezine jedinstvenosti i izvornog karaktera.

\subsection{Pravila koja uređuju položaj zaposlenika Europske unije}

Pitanja javne službe EU-a uređuju mnogobrojna pravila koja je potrebno razmotriti poštujući hijerarhiju pravnih normi pravnog sustava Unije. Sudska praksa Suda, Općeg suda i Službeničkog suda Europske unije također ima značajnu ulogu u definiranju pravila koja se primjenjuju na javnu službu EU-a. ${ }^{8}$

Primarno pravo. Primarno pravo nalazi se na vrhu hijerarhije izvora prava EU-a ${ }^{9}$ i obuhvaća ugovore o osnivanju europskih zajednica i Europske unije (osnivački ugovori) i izmjene i dopune tih ugovora, protokole koji su pridodani navedenim ugovorima te Povelju Europske unije o temeljnim pravima (Povelja).

Ugovori. Brojna temeljna načela sadržana u ugovorima obvezuju službenike u izvršavanju njihovih dužnosti, poput, primjerice, vrijednosti i ciljeva Unije navedenih u čl. 2. odnosno čl. 3. Ugovora o Europskoj uniji (UEU). Konkretnije, čl. 298 Ugovora o funkcioniranju Europske unije (UFEU), određuje da $» 1$. u obavljanju svojih zadaća, institucije, tijela, uredi i agencije Unije imaju potporu otvorene, učinkovite i neovisne europske administracije. 2. U skladu s Pravilnikom o osoblju i Uvjetima zaposlenja usvojenima na temelju čl. 336., Europski parlament i Vijeće uredbama, u skladu s redovnim zakonodavnim postupkom, utvrđuju odredbe u tu svrhu.« Usto, UFEU sadržava niz odredbi koje se odnose upravo na pitanja javne službe EU-a. Međutim, takve odredbe primarnog prava kojima se uređuju pitanja javne službe Unije nisu ujednačene ni sistematizirane, već su »raspršene « kroz cjelokupan tekst Ugovora. Nadalje, takve su odredbe često nepotpune i njihova primjena zahtijeva donošenje sekundarnog zakonodavstva od strane institucija (Andreone, 2015, str. 2; Dalle-Crode, 2008, str. 22). Primjerice, čl. 336. UFEU-a propisuje da »Europski parlament i Vijeće, uredbama, u skladu s redovnim zakonodavnim postupkom i nakon savjetovanja s ostalim zainteresiranim institucijama, utvrđuju Pravilnik o

${ }^{8}$ Za detaljan prikaz pravnih pravila koja uređuju javnu službu EU-a vidjeti: Andreone, 2015, str. 61-85; Andreone, 2016, str. 588-596; Pilorge-Vrancken, 2017, str. 12-30.

${ }^{9}$ Više o izvorima prava i hijerarhiji pravnih normi prava EU-a vidjeti u: Ćapeta \& Rodin, 2011, str. 10 -19; Craig \& de Búrca, 2015, str. 110-121. 
osoblju za dužnosnike [službenike] Europske unije i Uvjete zaposlenja ostalih službenika [ostalog osoblja] Unije.« Nadalje, čl. 270. UFEU-a Sudu Europske unije povjerava je nadležnost »u svim sporovima između Unije i njezinih službenika u granicama i prema uvjetima utvrđenima u Pravilniku o osoblju za dužnosnike [službenike] i Uvjetima zaposlenja za ostale službenike [ostalo osoblje] Unije.« Osim toga, člankom 340. UFEU-a određeno je da »u pogledu izvanugovorne odgovornosti Unija je, u skladu s općim načelima koja su zajednička pravima država članica, dužna naknaditi svaku štetu koju njezine institucije ili službenici prouzroče pri obavljanju svojih dužnosti« (st. 2.) te da se »osobna odgovornost službenikâ prema Uniji uređuje odredbama utvrđenima u Pravilniku o osoblju ili u Uvjetima zaposlenja koji se na njih primjenjuju« (st. 4.).

Dakle, samim ugovorima određeno je da poslove u institucijama EU-a obavljaju zaposlenici čija se prava i obveze uređuju propisima koje donose same te institucije i da o eventualnim sporovima koji bi nastali između tih službenika i institucije ne odlučuju nacionalni sudovi, već sudska tijela Unije. Jednako tako, ugovorima je propisana i izvanugovorna odgovornost Unije za štetu koju njezini službenici prouzroče u obavljanju svojih dužnosti.

Protokoli. Osim samih ugovora, odredbe o javnoj službi EU-a sadržavaju i protokoli i dodaci uz osnivačke ugovore. Sukladno čl. 51. UEU-a i sudskoj praksi, protokoli se smatraju sastavnim dijelom ugovora, s jednakom pravnom snagom (presuda 85/85, Komisija/Belgija). Važno je napomenuti da su porezni režim službenika institucija Unije i imunitet tih službenika od nadležnost nacionalnih sudova u pogledu radnji koje oni poduzimaju u službenom svojstvu, uređeni Protokolom br. 7. o povlasticama i imunitetima Europske unije (Protokol) i time integrirani u primarno pravo.

Primjerice, čl. 12. Protokola propisuje da su službenici i ostali zaposlenici Unije dužni plaćati porez u korist Unije na plaće i prihode koje im isplaćuje Unija te da su oslobođeni od plaćanja nacionalnih poreza na te plaće i prihode. Usto, čl. 13. tog Protokola određuje da se »pri primjeni poreza na dohodak, poreza na bogatstvo i poreza na nasljedstvo te pri primjeni konvencija o izbjegavanju dvostrukog oporezivanja sklopljenih među državama članicama Unije, za dužnosnike [službenike] i ostale službenike [zaposlenike] Unije koji isključivo radi obnašanja svojih dužnosti u službi Unije imaju boravište na državnom području države članice koja nije zemlja njihove porezne rezidentnosti, u trenutku stupanja u službu Unije smatra ..., kako u zemlji njihova stvarnog boravišta tako i u zemlji njihove porezne rezidentnosti, da su zadržali rezidentnost u potonjoj zemlji. ...« 
Nadalje, na temelju čl. 14. navedenog Protokola, »Europski parlament i Vijeće, uredbama, u skladu s redovnim zakonodavnim postupkom i nakon savjetovanja sa zainteresiranim institucijama, utvrđuju program prava iz socijalne sigurnosti za dužnosnike i ostale službenike Unije.«Dakle, odredbama primarnog prava popisana je obveza službenika institucija EU-a da plaćaju poreze u korist Unije, odnosno nadležnost Unije za prikupljanje doprinosa od svojih zaposlenika i za uređivanje pitanja njihova socijalnog osiguranja.

Povelja. Povelja, koja ima jednaku pravnu snagu kao ugovori, ${ }^{10}$ pisani je katalog temeljnih ljudskih prava koje Unija priznaje i štiti, primjenjuje se na sve akte sekundarnog prava Unije - pa tako i na Pravilnik o osoblju. Dakle, zaposlenici institucija s jedne strane uživaju prava zaštićena Poveljom EU-a, a s druge strane, u izvršavanju svojih dužnosti moraju poštovati temeljna prava građana. U tom pogledu, čl. 41. Povelje, kojim je zajamčeno pravo na dobru upravu, ima osobitu važnost.

Opća načela prava EU-a. Od početka procesa europske integracije, Sud je kroz svoju praksu priznao postojanje brojnih općih načela prava EU-a. ${ }^{11}$ U pogledu javne službe EU-a, ta su načela u bitnom inspirirana temeljnim ljudskim pravima zaštićenim Europskom konvencijom za zaštitu ljudskih prava i temeljnih sloboda (EKLJP). Na temelju čl. 6/3. UEU-a, »temeljna prava, kako su zajamčena Europskom konvencijom za zaštitu ljudskih prava i temeljnih sloboda i kako proizlaze iz ustavnih tradicija zajedničkih državama članicama, čine opća načela prava Unije.«

Naime, prije proglašenja Povelje, temeljna ljudska prava, pa tako i prava službenika Unije, bila su zaštićena kroz opća načela prava EU-a, koja su inspirirana i jamstvima temeljnih prava iz EKLJP-a. Upravo temeljna ljudska prava primjer su na kojem je vrlo uočljiv proces kodifikacije općih načela prava koja su se kristalizirala kroz sudsku praksu Suda (Ćapeta \& Rodin, 2011, str. 18). Unatoč tome što je Povelja postala obvezujuća, EKLJP i praksa Europskog suda za zaštitu ljudskih prava i dalje su važan izvor prava prilikom tumačenja odredbi Povelje.

Sekundarno pravo - Pravilnik o osoblju. Pored primarnog prava, glavni propis koji uređuje pitanja javne službe Unije jest Pravilnik o osoblju. Riječ

${ }^{10}$ Na temelju čl. 6/1. prvog podstavka UEU-a Povelja proglašena 2007. ima istu pravnu snagu kao i ugovori.

11 Više o općim načelima prava EU-a u: Ćapeta \& Rodin, 2011, str. 17-20. 
je o propisu koje je zajednički svim institucijama i agencijama EU-a ${ }^{12}$ i primjenjuje se na stalno zaposleno osoblje te na ostale kategorije zaposlenika. ${ }^{13}$ Pravilnik sadržava detaljne odredbe kojima se uređuju, među ostalim, zapošljavanje i razvoj karijere službenika, njihovi uvjeti rada, prava i obveze, ${ }^{14}$ primanja, stegovne mjere i pravni lijekovi.

Pravilnik o osoblju je uredba, koja je po svojoj pravnoj snazi izjednačena s ostalim uredbama. Stoga Pravilnik o osoblju obvezuje ne samo institucije i tijela Unije već i države članice jer ima sva obilježja određena čl. 288/2. UFEU-a. Odnosno, kako je Sud naveo u presudi 137/80 Komisija protiv Belgije: »iz navedenoga proizlazi da Pravilnik o osoblju, uz učinke koje ima u unutarnjem poretku (Unijine) administracije, obvezuje države članice

12 Osim za zaposlenike Europske središnje banke i Europske investicijske banke, koje imaju vlastite pravilnike o osoblju.

${ }^{13}$ Institucije Unije zapošljavaju oko 40.000 djelatnika, a službenici čine $75 \%$ zaposlenika, dok su preostalih $25 \%$ ostale kategorije zaposlenika na koje se primjenjuje drugi dio Pravilnika o osoblju - Uvjeti zaposlenja ostalih službenika [ostalog osoblja] Europske unije (Uvjeti zaposlenja), i to: »privremeno osoblje« (čl. 2. Uvjeta zaposlenja) i »ugovorno osoblje« (čl. 3.a Uvjeta zaposlenja). V. Dalle-Crode, 2008, str. 34. Broj radnih mjesta za svaku instituciju Unije naveden je u proračunskoj dokumentaciji za svaku financijsku godinu. Za 2017. ukupan broj radnih mjesta za sve institucije EU-a iznosio je 39.328 (http://ec.europa. eu/budget/biblio/documents/2017/2017_en.cfm).

14 Većina institucija donijela je pravila dobrog upravnog ponašanja kojima se pojašnjavaju obveze i dužnosti službenika propisane Pravilnikom o osoblju i drugim izvorima službeničkog prava (primjerice Vodič o obvezama dužnosnika i ostalih službenika Europskog parlamenta - kodeks ponašanja (http://www.europarl.europa.eu/atyourservice/hr /20150201PVL00050/Etika-i-transparentnost), Kodeks dobrog upravnog ponašanja u odnosu osoblja Europske komisije s javnošću (https://ec.europa.eu/info/about-european-commission/service-standards-and-principles/codes-conduct/staff_hr), Kodeks dobrog upravnog ponašanja Glavnog tajništva Vijeća Europske unije i njegova osoblja u njihovim profesionalnim odnosima s javnošću, itd.). Usto, Europski parlament prihvatio je na prijedlog europskog ombudsmana rezoluciju kojom se odobrava Europski kodeks o dobrom ponašanju zaposlenih u upravi, kojim se ombudsman služi pri obavljanju svoje dužnosti nadzornika i utvrđivanja slučajeva nepravilnosti u postupanju uprave (više o instituciji europskog ombudsmana na https://www.ombudsman.europa.eu). Jedna od ideja vodilja pri donošenju tog Kodeksa bilo je uklanjanje nejasnoća koje se pojavljuju zbog usporednog postojanja različitih kodeksa ponašanja za većinu europskih institucija te omogućavanje da sve institucije Unije primjenjuju ista načela u svojim odnosima s građanima (Dalle-Crode, 2008, str. 305-306). U Europski kodeks o dobrom ponašanju zaposlenih u upravi ugrađeno je 2012. pet temeljnih načela javne službe kojima se trebaju voditi službenici EU-a. Ta načela (posvećenost Europskoj uniji i njezinim građanima, integritet, objektivnost, poštovanje drugih i transparentnost) »predstavljaju postojeća očekivanja građana i upravnih službenika, ... već eksplicitno i implicitno ugrađena u Pravilnik o osoblju te ostale dokumente poput Financijske uredbe i Europskog kodeksa o dobrom ponašanju zaposlenih u upravi«, ali obuhvaćaju i druge standarde važne za pravilno i potpuno razumijevanje položaja službenika EU-a (https://www. ombudsman.europa.eu/en/resources/ publicserviceprinciples.faces). 
uvijek kada je njihova suradnja nužna za njegovu provedbu« (neslužbeni prijevod), što podrazumijeva da su u slučaju kada je za provedbu neke odredbe Pravilnika o osoblju potrebno donošenje nacionalnih provedbenih mjera, »države članice dužne usvojiti sve prikladne opće ili pojedinačne mjere« (neslužbeni prijevod) (presuda 137/80 Komisija/Belgija, t. 8 i 9). Pravilnikom o osoblju propisano je, među ostalim, da službenici plaćaju doprinose za sustav socijalne sigurnosti koji je zajednički institucijama Unije. Naime, u poglavlju 2. glave V. Pravilnika o osoblju, naslovljenom »Socijalna sigurnost«, u čl. 72.-84. određuje se doprinos, izražen postotkom osnovne plaće, koji službenici plaćaju za financiranje različitih rizika pokrivenih zajedničkim sustavom. ${ }^{15} \mathrm{U}$ istom poglavlju Pravilnika o osoblju nabrojena su socijalna davanja koja se dodjeljuju službenicima i članovima njihovih obitelji. Pored navedenog Pravilnika, svaka institucija donosi i opće odredbe za provedbu odredaba Pravilnika o osoblju. ${ }^{16}$

Ostali akti sekundarnog prava koji su važni za pravo javne službe EU-a. Uz Pravilnik o osoblju, postoji još niz akata sekundarnog prava koji su važni u pravu javne službe EU-a. Tako je, primjerice, porezni režim koji se primjenjuje na zaposlenike institucija propisan Uredbom br. 260/68, kojom je određen način obračuna i plaćanja poreza na dohodak koji se isplaćuje zaposlenicima Unije, dok se Uredbom br. 549/69 utvrđuje kategorija službenika i ostalih zaposlenika koji su obveznici plaćanja tog poreza (v. infra). Zatim, Uredba br. 1/58, kojom je utvrđeno jezično uređenje Europske unije, iznimno je važna za javnu službu EU-a jer se njome uređuje korištenje jezicima unutar institucija Unije i u komunikaciji građana s institucijama, a jednako tako važna je i pri zapošljavanju osoblja.

Direktive. Što se tiče direktiva - s obzirom na to da su, u načelu, upućene državama članicama - one ne mogu same po sebi nametati obveze institucijama Unije. Međutim, u određenim okolnostima, zaposlenici Unije mogu se pozivati na odredbe pojedinih direktiva u odnosu na institucije. ${ }^{17}$ Ponajprije, odredbe Pravilnika o osoblju mogu upućivati na odredbe poje-

15 Sukladno odredbama Pravilnika o osoblju, službenici institucija EU-a obvezno su osigurani u zajedničkom sustavu socijalnog osiguranja za službenike i ostalo osoblje Unije (régime commun d'assurance maladie, RCAM).

16 Više o općim odredbama za provedbu Pravilnika o osoblju u: Andreone, 2015, str. 20; Pilorge-Vrancken, 2017, str. 24.

17 Naime, brojne direktive predviđaju važna prava iz područja radnog i socijalnog prava, koja usto mogu bili povezana s temeljnim ljudskim pravima. Više o navedenoj temi u: Petrlík, 2014, str. 803-811. 
dine direktive i time je učiniti obvezujućom za institucije. Takav je slučaj, primjerice, s odredbom čl. 1e/2. Pravilnika o osoblju, koja propisuje da se službenicima osiguravaju »uvjeti rada u skladu s odgovarajućim zdravstvenim i sigurnosnim standardima koji odgovaraju barem minimalnim zahtjevima koji se primjenjuju u okviru mjera donesenih u tim područjima na temelju ugovora - čime se službenicima omogućuje zaštita koju pružaju direktive donesene u području socijalnog prava.

Nadalje, institucije se u okviru svoje organizacijske autonomije mogu internim aktima same obvezati na poštovanje određenih obveza predviđenih pojedinom direktivom ili izričito uputiti na njezine odredbe. Budući da su interni akti institucija hijerarhijski podređeni Pravilniku o osoblju, pozivanjem na direktive ne može se postići rezultat koji bi mu bio protivan. Međutim, odredbe neke direktive mogu stvarati obveze za pojedinu instituciju ako je ta odredba izraz nekog općeg načela prava koje su institucije dužne poštovati kao takvo (presuda F-65/07 Aayban i dr./Europski parlament, t. 113). U takvoj situaciji, s obzirom na to da su opća načela prava nadređena sekundarnim izvorima prava, moguće je pozivanje na odredbe direktive iako je protivna odredbama Pravilnika o osoblju. Isto vrijedi i za prava zaštićenih Poveljom - ako je pojedina odredba neke direktive izraz nekog temeljnog prava zajamčenog Poveljom, ona omogućava izuzimanje iz primjene neke odredbe Pravilnika o osoblju (Pilorge-Vrancken, 2017, str. 29).

Konačno, u pravu javne službe EU-a direktive mogu imati i posredan učinak. ${ }^{18}$ Sukladno praksi Službeničkog suda Europske unije, obveza lojalne suradnje između država članica i europskih institucija nameće obvezu potonjima da osiguraju dosljednost između svoje zakonodavne aktivnosti na razini Unije, osobito kada je namijenjena državama članicama, i svoje vlastite interne politike. Stoga su institucije dužne odredbe Pravilnika o osoblju tumačiti u najvećoj mogućoj mjeri u skladu s tekstom i svrhom direktiva kako bi se ostvarili rezultati koji se njima žele postići (presude F-65/07 Aayban $i d r$. t. 118 - 120; spojeni predmeti F-137/07 i F-8/08 Adjemian $i d r$., t. 93, 112 - 114 i 117). Sudska praksa priznaje mogućnost pozivanja na posredni učinak direktiva na institucije u pitanjima prava javne službe EU-a u mjeri koja je spojiva s odredbama Pravilnika o osoblju. U praksi to znači da institucije moraju poštovati obveze propisane direktivama, osim ako postoji jasna odredba Pravilnika o osoblju koja im nalaže da postupe drugačije (Pilorge-Vrancken, 2017, str. 30; Petrlík, 2014, str. 808).

18 Više o posrednom ili interpretativnom učinku europskog prava u: Ćapeta \& Rodin, 2011, str. 75- 81. 
Sudska praksa Suda Europske unije. Člankom 270. UFEU-a Sudu Europske unije povjerena je nadležnost $\gg$ u svim sporovima između Unije i njezinih službenika u granicama i prema uvjetima utvrđenima u Pravilniku o osoblju za dužnosnike [službenike] i Uvjetima zaposlenja za ostale službenike [ostalo osoblje] Unije.« Opći sud Europske unije danas je (ponovo) nadležan za rješavanje službeničkih sporova u prvom stupnju, ${ }^{19} \mathrm{a}$ protiv njegovih se odluka može Sudu podnijeti žalba ograničena na pravna pitanja. ${ }^{20}$ Presude Suda EU-a obvezuju institucije na temelju čl. 266/1. UFEU-a, sukladno kojemu »institucija, tijelo, ured ili agencija čiji je akt proglašen ništavim, ili čije je propuštanje djelovanja proglašeno protivnim ovom Ugovoru, dužni su poduzeti potrebne mjere kako bi postupili sukladno presudi Suda.«

Od početaka integracijskog procesa doneseno je više tisuća presuda u predmetima javne službe EU-a. Dale su iznimno važan doprinos definiranju pravila koja uređuju status zaposlenika institucija. Međutim, ta je praksa Suda EU-a ostala relativno nepoznata pravnoj javnosti. ${ }^{21}$ Prije prelaska na analizu presude u predmetu de Lobkowicz, u nastavku ćemo prikazati osnovne postavke uređenja koordinacije sustava socijalne sigurnosti u Uniji.

\section{Koordinacija sustava socijalne sigurnosti u EU}

Uređenje pitanja socijalne politike u Uniji u nadležnosti je država članica: one same odlučuju koje će povlastice primati građani i pod kojim uvjetima. Uredbe o koordinaciji sustava socijalne sigurnosti dio su europskog

19 Službenički sud bio je nadležan za sporove između institucija Europske unije i njihova osoblja u vezi s radnim odnosom i sustavom socijalne sigurnost od svog osnivanja 2004. do svog ukidanja 2016., kada je temeljem Uredbe (EU, Euratom) 2016/1192 Europskog parlamenta i Vijeća od 6. srpnja 2016. o prijenosu na Opći sud nadležnosti za odlučivanje u prvom stupnju o sporovima između Europske unije i njezinih službenika (SL 2016., L 200, str. 137) ta nadležnost vraćena Općem sudu. Za povijesni pregled razvoja nadležnosti u službeničkim sporovima i reformu Općeg suda v. Stanković, 2016.

20 Čl. 56. i 58. Protokola (br. 3) o Statutu Suda Europske unije, v. supra.

21 Prema podacima dostupnim na pretraživaču sudske prakse na web stranici Suda https://curia.europa.eu/jcms/jcms/j_6/hr/, preko 4.000 odluka (4.738 na dan 9.8.2017.) odnosilo se na Pravilnik o osoblju. Unatoč činjenici što je riječ o vrlo bogatoj praksi, ostala je gotovo nezamijećenom u pravnoj javnosti. Vjerojatno uzroci, među ostalim, leže i u tome što je riječ o grani prava koja se odnosi na relativno mali broj adresata te u tome što je praksa najčešće dostupna samo na jeziku postupka i francuskom jeziku. V. O’Leary, 2011. 
acquisa još od samih početaka integracije ${ }^{22}$ i određuju koje će se nacionalne odredbe primjenjivati na građane koji žive u drugoj državi članici. Cilj je tih pravila osigurati slobodno kretanje radnika, ${ }^{23}$ odnosno uspostavu sustava koji će omogućiti da se na osobe koje se kreću na području Unije primjenjuje zakonodavstvo socijalne sigurnosti samo jedne države članice kako bi se izbjeglo preklapanje zakonodavstava država članica i problemi koji bi iz toga mogli proizaći. Danas je to područje uređeno Uredbom br. 883/2004 (uredba o koordinaciji). Ta je uredba izmijenjena Uredbom br. 988/2009 i dopunjena Uredbom br. 987/2009 (provedbena uredba). ${ }^{24}$

${ }^{22}$ Riječ je o Uredbi br. 3 i njezinoj provedbenoj Uredbi br. 4. Izvori uredbi br. 3 i 4 prethode Rimskim ugovorima i nalaze se već u Ugovoru EZUČ-u s obzirom na to da je jedan od ciljeva tog Ugovora bio osigurati slobodno kretanje radnika u sektoru ugljena, a problemi socijalne sigurnosti ocijenjeni su kao prepreka tom cilju (Roberts, 2010, str. 17). Naime, već tada se smatralo da je koordinacija sustava socijalne sigurnosti nužna za slobodno kretanje radnika. Uredba br. 3 zamijenjena je Uredbom br. 1408/71, koja je dopunjena (provedbenom) Uredbom br. 574/72.

23 Uredbom br. 1408/71 prvotno su bili obuhvaćeni samo radnici, no od 1. srpnja 1982. njezino je područje primjene prošireno i na samozaposlene osobe. Tom su Uredbom bili obuhvaćeni i članovi obitelji radnika i samozaposlenih osoba te osobe koje uzdržavaju, kao i osobe bez državljanstva i izbjeglice. Uredbom br. 1606/98 Vijeće je proširilo područje primjene Uredbe br. 1408/71 kako bi izjednačilo status javnih službenika s onim ostalog stanovništva u pogledu općih zakonskih mirovinskih prava u državama članicama. Uredbom br. 307/1999 njezino je područje primjene dodatno prošireno kako bi se obuhvatile sve osigurane osobe, a posebno studenti i osobe koje nisu u plaćenom radnom odnosu. Uredbom br. 859/2003 područje primjene Uredbe 1408/71 ponovo je prošireno kako bi se njome obuhvatili i državljani trećih zemalja pod uvjetom da legalno borave na teritoriju EUa. Uredbom br. 1231/2010., ta modernizirana pravila o koordinaciji socijalnog osiguranja u EU-u proširena su na državljane trećih zemalja koji legalno borave u EU-u i nalaze se u prekograničnoj situaciji (koji dotad samo zbog svoje nacionalnosti nisu bili obuhvaćeni tim pravilima). Sad su obuhvaćeni i članovi njihovih obitelji te nadživjele osobe ako se nalaze u EU-u. Pogranični radnici, koji rade kao zaposlenici ili samozaposlene osobe u jednoj državi članici, a borave u drugoj državi članici u koju se u pravilu vraćaju svaki dan ili barem jednom tjedno također su obuhvaćeni zakonodavstvom koje je na snazi. Upućeni radnici izniman su slučaj jer oni nisu integrirani na tržište rada države članice domaćina, već ih tamo šalje njihovo poduzeće radi privremenog angažmana. Oni su i dalje socijalno osigurani u svojoj matičnoj državi članici u razdoblju od najviše 24 mjeseca. Od države članice u kojoj borave mogu primiti samo zdravstvene usluge. V.: http://www.europarl.europa.eu/atyourservice/hr/ displayFtu.html?ftuId=FTU_5.10.4.html. Više o personalnom i materijalnom dosegu koordinacijskih uredbi i relevantnoj praski Suda u: Pennings, 2014.; Van Raepenbusch, 2009.

${ }^{24}$ Uredba br. 883/2004 i Uredba br. 987/2009 izmijenjene su Uredbom br. 1372/2013, kako bi se sadržaj tih uredaba uskladio s izmjenama u nacionalnim zakonodavstvima država članica ili kako bi se pojednostavnila primjena tih uredaba. Posljednja izmjena navedenih uredaba izvršena je Uredbom br. 1368/2014. Komisija je u prosincu 2016. kao dio paketa mjera za mobilnost radne snage predložila izmjenu Uredbe br. 883/2004 i provedbene Uredbe (EZ) br. 987/2009 kako bi se odgovorilo na nove socijalne i gospodarske okolnosti u državama članicama. Izmjena je usmjerena na uže povezivanje isplaćivanja naknada s državom članicom koja je ubirala doprinose za socijalno osiguranje, čime bi sustav trebao postati 
Pravna osnova za donošenje navedenih pravila jest čl. 48. UFEU-a, koji je dio glave IV. Ugovora, naslovljene »Slobodno kretanje osoba, usluga i kapitala«, a upravo mjesto u Ugovoru na kojem se nalazi važno je za njegovo tumačenje. Tako se Sud EU-a, prilikom tumačenja pravila koordinacijske Uredbe, često poziva na smještaj pravne osnove pravila o koordinaciji sustava socijalne sigurnosti, navodeći kako se zbog svog sadržaja i smještaja, čl. 48. treba tumačili tako da se osigura sloboda kretanja radnika, a ne samo kao tehničko pravilo o koordinaciji (Pennings, 2014, str. 119).

Za koordinaciju sustava socijalne sigurnosti važan je i čl. 45. UFEU-a, koji zabranjuje svaku diskriminaciju na temelju državljanstva među radnicima iz država članica u vezi sa zapošljavanjem, primicima od rada i ostalim uvjetima rada i zapošljavanja. Taj se članak često navodi pri tumačenju odredbi Uredbe ili pri odlučivanju o pitanjima koordinacije koji su izvan dosega čl. 48. UFEU-a (Pennings, 2014, str. 118).

Osnovna načela koordinacije sustava socijalne sigurnosti u Uniji jesu načelo jednakog postupanja (zaposlene i samozaposlene osobe iz drugih država članica imaju jednaka prava i obveze kao i državljani zemlje domaćina; pravo na jednako postupanje bezuvjetno se primjenjuje na svaku zaposlenu ili samozaposlenu osobu iz druge države članice koja je u državi domaćinu boravila tijekom određenog razdoblja), načelo primjene prava jedne države članice (lex loci labori, kao opće pravilo), načelo zbrajanja razdoblja (pri donošenju odluke o tome ispunjava li radnik uvjete koji se odnose na trajanje osiguranja ili zaposlenja nadležna država članica mora uzeti u obzir razdoblja osiguranja i zaposlenja ispunjena u okviru zakonodavstva druge države članice), prijenos naknada u drugu državu (naknade u okviru socijalnog osiguranja mogu isplaćivati diljem Unije te se njime državama članicama zabranjuje da isplatu tih naknada ograničavaju na osobe koje borave na njihovu teritoriju, no to se ne odnosi na sve vrste naknada socijalnog osiguranja), i konačno, načelo lojalne suradnje (Uredba br. 883/2004, čl. 4.-7. i 10.; Van Raepenbusch, 2009).

Praksa Suda EU-a o tumačenju navedenih uredbi je vrlo bogata, kako u pogledu područja primjene tih uredbi (materijalnog i osobnog) i njihove povezanosti s međunarodnim i bilateralnim konvencijama tako i u pogledu primjene osnovnih načela koordinacije sustava socijalne sigurnosti u

pravednijim. Prijedlogom se također važeći zakonski propisi usklađuju s nedavnom sudskom praksom o pristupu socijalnim naknadama za gospodarski neaktivne građane. V. http://www. europarl.europa.eu/atyourservice/hr/displayFtu.html?ftuId=FTU_5.10.4.html. 
Uniji, a imala je iznimno važan utjecaj na jačanje socijalne zaštite osoba koje su se koristile svojim pravom na slobodno kretanje unutar Unije. ${ }^{25}$

\section{Načelo primjene jednog socijalnog zakonodavstva (predmet C-623/13 de Ruyter)}

Kao što je uvodno navedeno, Sud Europske unije nedavno je imao priliku odlučivati o predmetu de Lobkowicz, u kojem se postavilo pitanje može li država članica nametnuti obvezu sudjelovanja u financiranju svoga sustava socijalnog osiguranja svojim poreznim rezidentima koji su obveznici sustava socijalnog osiguranja Europske unije.

Sporni nacionalni (francuski) propis bio je već predmetom odlučivanja pred Sudom EU-a u predmetu de Ruyter, ali uz drugačije činjenične okolnosti. S obzirom na njezinu relevantnost, u nastavku ćemo dati kratak prikaz presude suda u tome predmetu.

G. de Ruyter bio je zaposlen u Nizozemskoj i stoga se, u skladu s načelom lex loci laboris, na njega primjenjivalo nizozemsko zakonodavstvo o socijalnoj sigurnosti. Međutim, imao je prebivalište u Francuskoj i za njega je bilo mjerodavno francusko porezno pravo. Konkretno, kao francuski porezni rezident, morao je plaćati »opće socijalne doprinose u korist nacionalnog fonda za obiteljske naknade, fondova starosne solidarnosti i sustava obveznog zdravstvenog osiguranja iz dohodaka od imovine na temelju netoiznosa na osnovi kojeg se obračunava porez na dohodak, osobito dohodaka od nekretnina, doživotne rente i dohodaka od kapitala, »doprinos za podmirenje socijalnog duga«, koji se obračunava na temelju istih dohodaka, socijalni namet od $2 \%$ i dodatni doprinos od $0,3 \%$ uz taj namet.

Ti nameti imali su dva zajednička obilježja: prvo, bili su uređeni općim poreznim zakonikom i plaćali su se na temelju netoiznosa na osnovi kojeg se obračunavao porez na imovinu. G. de Ruyteru su obračunati na temelju doživotnih renti koje su mu isplaćivala dva nizozemska društva za osigura-

${ }^{25}$ Van Raepenbusch je u svom referatu povodom pedeset godina koordinacije socijalne sigurnosti u Uniji (Van Raepenbusch, 2009.) analizirao, među ostalim, broj predmeta koji su pokrenuti pred Sudom u svezi s tumačenjem koordinacijskih uredaba. Tako se na dan 31. ožujka 2009., od 5055 presuda koje je Sud donio u postupcima po zahtjevima za prethodnu odluku, 509 presuda odnosilo na tumačenje uredaba 1408/71 i 574/72 (prethodno uredaba 3 i 4) - dakle jedna desetina presuda. Navodi i da je taj omjer bio još i veći na dan 1 . siječnja 1980. (122 presude povodom zahtjeva za prethodnu odluku od ukupno 599 presuda), prije znatnog proširenja nadležnosti Zajednice. 
nje. Drugo, ti su nameti bila namijenjeni financiranju francuskog sustava socijalne sigurnosti (Daxkobler, 2015, str. 618).

G. de Ruyter osporio je osnovanost takvog oporezivanja, smatrajući da je nametnuta mu obveza plaćanja u dva različita sustava socijalne sigurnosti protivna načelu primjene socijalnog zakonodavstva jedne države članice, primjenjivog na temelju čl. 13. Uredbe br. 1408/71, s obzirom na to da su ti dohoci već bili podvrgnuti sličnim nametima u Nizozemskoj (t. 12).

Slijedeći mišljenje nezavisne odvjetnice Sharpston, Sud je presudio u korist G. de Ruytera. Sud je pojasnio da je odlučujući čimbenik za primjenu Uredbe br. 1408/71 postojanje izravne i značajne veze između odredbe o kojoj je riječ i zakonodavstva koje uređuje grane socijalne sigurnosti navedene u čl. 4. Uredbe br. 1408/7, a da sama činjenica da nacionalno zakonodavstvo neki namet kvalificira kao porez ne znači da taj isti namet ne može ulaziti u područje primjene Uredbe br. 1408/71 (t. 24). Isto tako, Sud je naveo da pitanje postojanja protuusluge nije relevantno za potrebe primjene Uredbe br. 1408/71 jer je odlučujući kriterij za njezinu primjenu to da je određeni doprinos posebno namijenjen financiranju sustava socijalnog osiguranja države članice. ${ }^{26}$

Osim toga, Sud je istaknuo da se, s obzirom na cjelovitost sustava kolizijskih pravila predviđenog Uredbom br. 1408/71, osobito u pogledu načela primjene zakonodavstva samo jedne države članice u području socijalne sigurnosti navedenog u članku 13. te Uredbe, čija je svrha izbjeći teškoće koje mogu nastati slijedom istodobne primjene nekoliko nacionalnih zakonodavstava i otkloniti nejednako postupanje prema osobama koje se kreću unutar Unije, primjena Uredbe br. 1408/71 ne može ograničiti na dohotke koje te osobe ostvaruju u okviru svojih radnih odnosa jer bi inače došlo do razlika u primjeni čl. 13. te Uredbe ovisno o podrijetlu dohodaka tih osoba (t. 31-38).

Dakle, rasuđivanje Suda temeljilo se, u bitnom, na strogom poštovanju zabrane preklapanja zakonodavstava o socijalnoj sigurnosti i kolizijskog

${ }^{26}$ Pitanje je li riječ o porezu ili socijalnom doprinosu važno je zbog toga što u području poreznog prava ne postoji sustav koordinacije poput onog za socijalno osiguranje (nego se taj problem u pravilu rješava ugovorima o izbjegavanju dvostrukog oporezivanja). Stoga, u skladu s načelom teritorijalnosti, država ima pravo oporezivati svjetski dohodak osoba koje su njezini rezidenti (»načelo svjetskog dohotka« ili »načelo neograničene porezne obveze«). U pogledu nerezidenata, države imaju samo pravo oporezivati dohodak koji potječe od izvora u toj državi (»načelo izvora dohotka« ili »načelo ograničene porezne obveze«). Prema ustaljenoj praksi Suda, dvostruko oporezivanje istog dohotka iste osobe nije protivno temeljnim pravima. O razgraničenju između doprinosa za socijalno osiguranje i poreza v. Daxkobler, 2015, str. 616-623. 
pravila koji su predviđeni čl. 13 Uredbe br. 1408/71, odnosno na isključivoj nadležnosti zakonodavstva o socijalnoj sigurnosti države članice zaposlenja. ${ }^{27}$

U presudi koja je predmet analize u ovom radu postavilo se pitanje obveze plaćanja iste vrste nameta osobe koja je također francuski porezni rezident, ali, za razliku od G. de Ruytera, nije obveznik socijalnog osiguranja u drugoj državi članici, već je službenik Europske unije. Upravo činjenica da je riječ o službeniku Unije otvara jednu sasvim novu dimenziju pravne problematike te se postavilo pitanje je li na njega primjenjivo rješenje iz presude de Ruyter.

\section{Analiza presude Suda u predmetu C-690/15 de Lobkowicz}

Postupak u predmetu povodom kojeg je donesena presuda koju analiziramo vodio se između W. de Lobkowicza, službenika Europske komisije umirovljenog 2016., i francuskog Ministarstva javnih financija, a odnosio se na obvezu plaćanja socijalnih doprinosa na dohotke od nekretnina koji je W. de Lobkowicz ostvario u Francuskoj u razdoblju od 2008. do 2011. Naime, budući da temeljem čl. 13. Protokola (v. supra), službenici Unije tijekom cijele svoje karijere zadržavaju poreznu rezidentnost u državi članici na čijem su području imali poreznu rezidentnost u trenutku stupanja u službu, W. de Lobkowicz porezni je rezident u Francuskoj, neovisno o tome što se radi obnašanja svojih dužnosti u službi Unije odselio u drugu državu članicu. ${ }^{28}$ Usto, kao službenik Unije, W. de Lobkowicz, plaća doprinose za sustav socijalne sigurnosti koji je zajednički institucijama Unije (v. supra). Nacionalni sud uputio je pitanje Sudu EU-a tražeći tumačenje o tome protivi li se pravu Unije nametanje obveze plaćanja socijalnih doprinosa službeniku Europske unije u državi članici u kojoj je porezni

${ }^{27}$ U toč. 56 svog mišljenja nezavisna odvjetnica Sharpston kvalificirala je pravilo kojim se zabranjuje preklapanje sustava iz čl. 13/1. Uredbe br. 1408/71 kao »apsolutno pravilo« koje podliježe samo iznimkama iz čl. 14.c i čl. 14.f te Uredbe.

${ }^{28}$ Kako je nezavisni odvjetnik Mengozzi pojasnio u t. 32 svoga mišljenja u predmetu de Lobkowicz, čl. 13. Protokola temelji se na pravnoj fikciji u skladu s kojom službenici institucija tijekom cijele karijere zadržavaju svoju poreznu rezidentnost, odnosno središte svojih interesa, u državi članici na čijem su području imali stalnu adresu u trenutku stupanja u službu. Dakle, osobe koje su se iselile iz Republike Hrvatske radi stupanja u službu EU-a i dalje su porezni rezidenti Republike Hrvatske. 
rezident, na temelju dohodaka od nekretnina ostvarenih u toj državi članici. U svom je zahtjevu naveo da je riječ o nametima koji na temelju presude de Ruyter ulaze u područje primjene Uredbe br. 1408/71, ali da je u konkretnom slučaju riječ o osobi koja je službenik Unije pa se on ne može smatrati radnikom u smislu pravila o koordinaciji sustava socijalne sigurnosti u Uniji (Ferlini, C-411/98) te se na njega ne može primijeniti načelo primjene zakonodavstva samo jedne države članice iz čl. 13. te Uredbe. Nacionalni sud je naveo i kako smatra da, iako službenici Unije imaju status radnika u smislu odredbi čl. 45. UFEU-a, taj članak ipak ne propisuje nijedan opći kriterij za raspodjelu nadležnosti između država članica i institucija Unije što se tiče financiranja socijalne sigurnosti, prema kojem bi se, kao što to navodi W. de Lobkowicz, njegovo podvrgavanje tim doprinosima moralo smatrati »diskriminatornom mjerom $« u$ smislu navedenog članka (t. 24).

Dakle, iz navoda nacionalnog suda u bitnom proizlazi da je upoznat $\mathrm{s}$ praksom Suda u pogledu spornog »poreza« te da W. de Lobkowicz ne bi bio dužan platiti navedene socijalne namete kad bi bio osiguran u drugoj državi članici, no pita se bi li nametanje takve obveze osobi koja je već osigurana u sustavu socijalnog osiguranja EU-a bilo u skladu s pravom Unije. Međutim, unatoč tome što je W. de Lobkowicz osiguran u sustavu socijalnog osiguranja Unije, rasprava među zainteresiranim stranama nije se usmjerila na pravila koja uređuju status službenika EU-a, već su one svoja očitovanja usredotočile na pitanje mogućnosti primjene načela jednog socijalnog zakonodavstva na okolnosti konkretnog slučaja na temelju samog čl. 45. UFEU-a, odnosno na pitanje proizlazi li to načelo izravno iz čl. 45. UFEU-a te se u tom pogledu nisu složile.

Naime, Komisija i W. de Lobkowicz tvrdili su da se rješenje Suda iz presude u predmetu de Ruyter može primijeniti na ovaj predmet na temelju tumačenja čl. 45. UFEU-a, jer je načelo primjene jednog socijalnog zakonodavstva sadržano u odredbama tog članka. S druge strane, francuska vlada iznijela je suprotnu argumentaciju i tvrdila da je načelo primjene zakonodavstva jedne države članice propisano samo uredbama br. 1408/71 i br. 883/2004 pa da stoga samo radnici koji su obuhvaćeni područjem primjene tih uredbi (što nije slučaj sa službenicima Unije) mogu ostvariti korist na temelju presude u predmetu de Ruyter. Osim toga, francuska vlada tvrdila je da ni u primarnom pravu ni u sekundarnom pravu Unije ne postoji ekvivalentno načelo, pa da je stoga W. de Lobkowicz obveznik spornih doprinosa.

Međutim, nezavisni odvjetnik Mengozzi u svom je mišljenju podsjetio na to da je Sud na pitanje proizlazi li načelo primjene zakonodavstva samo 
jedne države članice izravno iz čl. 45 UFEU-a već negativno odgovorio u presudi C-57/90, Komisija/Francuska, kao i da kasnija sudska praksa Suda nije opovrgnula stav iz te presude. Stoga je te zaključio da, »iako načelo primjene zakonodavstva samo jedne države članice u području socijalne sigurnosti zasigurno pridonosi poticanju slobodnog kretanja radnika unutar Unije jer se na njih primjenjuje samo jedno zakonodavstvo u području socijalne sigurnosti, to načelo u ovoj fazi razvoja prava Unije ne proizlazi izravno iz čl. 45. UFEU-a odnosno, u skladu s riječima Komisije, nije 'sastavni dio' te odredbe.« (t. 59 i 64).

Nastavno je istaknuo kako se smatra da se činjenica da je situacija W. de Lobkowicza uređena Pravilnikom o osoblju ne smije zanemariti ni podcijeniti, odnosno da ona ne smije dovesti do davanja prednosti ispitivanju prethodnog pitanja sa stajališta čl. 45. UFEU-a, već upravo sa stajališta Pravilnika o osoblju (t. 69). Dakle, tek je nezavisni odvjetnik u svom mišljenju upozorio na potrebu razmatranja predmetnog slučaja s aspekta odredaba Pravilnika o osoblju.

U svojoj analizi merituma ovog predmeta Sud je slijedio mišljenje nezavisnog odvjetnika i odluku donio upravo na temelju odredaba koje uređuju status službenika Unije. Rasuđivanje Suda temeljilo se, u bitnom, na nadležnosti Unije za uređivanje statusa njezinih službenika te na načelu lojalne suradnje država članica i institucija Unije i obvezi država članica da poštuju pravo Unije prilikom izvršavanja svojih nadležnosti.

Naime, Sud je podsjetio na to da službenici Unije, iako mogu imati svojstvo radnika migranta u smislu čl. 45. UFEU-a kao državljani jedne države članice koji rade na državnom području druge države članice koja nije njihova država podrijetla (t. 35), nisu podvrgnuti nacionalnom zakonodavstvu u području socijalne sigurnosti, nego je njihova pravna situacija u pogledu njihovih obveza u području socijalnog osiguranja »obuhvaćena područjem primjene prava Unije zbog njihove povezanosti s Unijom na temelju radnog odnosa « (t. 38) i obvezno su osigurani u zajedničkom sustavu socijalne sigurnosti institucija Unije (t. 36 i 27). Stoga se oni, kako je prije presudeno u presudi Ferlini, ne mogu smatrati »radnicima « u smislu uredbi br. $1408 / 71$ i br. $883 / 2004$ te se na njih ne može primijeniti načelo primjene zakonodavstva samo jedne države članice iz čl. 13. te Uredbe (t. 23 i 35$).{ }^{29}$

29 Skrećemo pozornost na razmišljanja o osobnom dosegu koordinacijskih uredbi koje je nezavisni odvjetnik iznio u t. 78 svog mišljenja u ovom predmetu, prema kojemu službenici Unije nisu obuhvaćeni koordinacijskim uredbama zbog toga što je u vrijeme njihova donošenja status tih službenika već bio uređen Pravilnikom o osoblju: »Međutim, s obzirom 
Sud je, nadalje, podsjetio na obvezu država članica da poštuju pravo Unije prilikom izvršavanja svojih nadležnosti, što za konkretan slučaj znači da su pri uređenju vlastitih sustava socijalne sigurnosti dužne poštovati pravila koja uređuju radni odnos službenika i Unije. Potom je pojasnio da je odredbama Protokola (dakle primarnog prava), s jedne strane, njegovim čl. 12. uspostavljena u korist Unije porezna obveza njezinih službenika za dohodak koji im ona isplaćuje te, posljedično, oslobođenje od plaćanja nacionalnih poreza na te iznose, ${ }^{30}$ a s druge je strane, njegovim čl. 14., institucijama Unije povjerena nadležnost za uređenje sustava socijalne sigurnosti njezinih službenika (t. 41).

Sud je iz navedenog zaključio da te odredbe treba shvatiti tako da se »podrazumijeva da su iz nadležnosti država članica izuzete obveza osiguranja dužnosnika (službenika) Unije u nacionalnom sustavu socijalne sigurnosti i obveza tih dužnosnika (službenika) da doprinose financiranju takvog sustava«, odnosno da je isključivo Unija nadležna za određivanje pravila socijalnog osiguranja za svoje službenike (t. 41 i 44).

Nakon toga, podsjetio je na pravnu prirodu Pravilnika o osoblju, koji je uspostavljen Uredbom br. 259/68 i »posjeduje sva obilježja navedena u čl. 288. UFEU-a, u skladu s kojim uredba ima opću primjenu, obvezujuća je u cijelosti i izravno se primjenjuje u svim državama članicama« te naveo da stoga države članice obvezuje Pravilnik o osoblju, a posljedično tome i sustav socijalnih doprinosa koji je njime uspostavljen (t. 42).

Usto, Sud je naglasio da pravila o socijalnom osiguranju službenika sadržana u Protokolu i Pravilniku o osoblju imaju ulogu analognu onoj koju imaju pravila o koordinaciji sustava socijalne sigurnosti jer se njima zabranjuje obveza službenika Unije da doprinose u različite sustave iz tog područja (t. 45).

Konačno, naveo je da bi takav propis ugrozio jednako postupanje među službenicima Unije i stoga obeshrabrio obavljanje profesionalne djelatnosti unutar institucija Unije, s obzirom na to da bi neki službenici bili obvezani doprinositi ne samo u zajednički sustav socijalne sigurnosti institucija Unije

na povezanost između Pravilnika o osoblju koji je, podsjećam, donesen 1968. i uredbi br. 1408/71 i br. 883/2004, čini se posve nevjerojatnim da je, u kategoriji radnika migranata, zakonodavac Unije htio isključiti dužnosnike [službenike] i članove privremenog osoblja Unije iz načela primjene zakonodavstva samo jedne države članice u području socijalne sigurnosti s obzirom na to da se to zakonodavstvo za njih sastoji od relevantnih odredbi Pravilnika o osoblju. Naprotiv, ti dužnosnici i članovi privremenog osoblja Unije nisu obuhvaćeni područjem primjene tih uredbi jer se za njih već primjenjuje RCAM koji je uspostavljen Pravilnikom o osoblju.«

30 To je trenutačno jedini porezni oblik koji predstavlja izravni prihod proračuna EUa. Detaljnije o tome u: Mijatović, Perić, \& Lerman, 2012, str. 47. 
nego i u nacionalni sustav socijalne sigurnosti (t. 47). Dakle, Sud je okosnicu svoga obrazloženja izgradio na isključivoj nadležnosti Unije za uređenje pitanja socijalnog osiguranja svojih službenika i dužnosti država članica da poštuju pravila donesena u izvršavanju te njezine nadležnosti, naglasivši pritom da je uloga tih pravila istovjetna ulozi koordinacijskih pravila.

$\mathrm{Na}$ temelju svega iznesenoga, Sud je zaključio da nacionalni propis poput onoga o kojemu je riječ u glavnom postupku povređuje isključivu nadležnost koja je Uniji dodijeljena čl. 14. Protokola i relevantnim odredbama Pravilnika o osoblju, osobito onima koje utvrđuju obvezne doprinose službenika Unije radi financiranja sustava socijalne sigurnosti.

Naime, kao što je prije navedeno, riječ je o nacionalnom propisu o kojemu je Sud već odlučio u predmetu de Ruyter, naglasivši da namet koji je izravno namijenjen financiranju sustava socijalne sigurnosti (postoji izravna i značajna veza između odredbe o kojoj je riječ i zakonodavstva koje uređuje grane socijalne sigurnosti) podliježe pravilima o koordinaciji sustava socijalne sigurnosti, neovisno o tome kako je definirano u nacionalnom sustavu. Međutim, iako je o tome pitanju već bilo odlučeno dvije godine prije, činjenica da je riječ o službeniku Unije potaknula je daljnju raspravu i sagledavanje te problematike iz druge perspektive - da bi u konačnici došli do istog zaključka, ali, ako što smo vidjeli, na drugoj pravnoj osnovi. Dakle, iako se na službenike EU-a ne primjenjuju pravila o koordinaciji sustava socijalne sigurnosti EU-a, sukladno presudi de Lobkowicz, službenici Unije dužni su uplaćivati doprinose za socijalno osiguranje samo u sustavu socijalnog osiguranja za službenike i ostalo osoblje Unije (odnosno prema jednom »zakonodavstvu«) jer su njihove financijske obveze u području socijalne sigurnosti uređene Protokolom i Pravilnikom o osoblju i izuzete su iz nadležnosti država članica pa im države članice ne mogu nametnuti obvezu financiranja svojih sustava socijalnog osiguranja, neovisno o tome kako se ti nameti kvalificiraju u nacionalnom sustavu.

\section{Zaključak}

Predmet de Lobkowicz bio je povod da se pred Sudom EU-a (ponovo) raspravi uređenje socijalnog osiguranja zaposlenika institucija Unije. Ono što je u ovom predmetu odmah uočljivo, već iz samih navoda nacionalnog suda i stranaka u postupku pred Sudom, jest činjenica da pravni status službenika EU-a nije dovoljno rasvijetljen ni poznat u državama članicama Unije, a ponekad ni unutar samih institucija. Upravo takva situacija 
upućuje na potrebu da se ta pravila učine pristupačnijima, osobito imajući u vidu cilj tih pravila i kontekst njihova donošenja.

Službenici institucija Unije, za razliku od ostalih »radnika«, ne moraju se koristiti pravom na slobodu kretanja da bi se na njih primijenilo pravo Unije - njihov je status uređen odredbama prava Unije upravo zbog njihova radnog odnosa s institucijama EU-a.

Naime, svrha navedenih pravila jest omogućiti institucijama Unije nesmetano obavljanje njihovih zadaća kroz, među ostalim, zaštitu ravnopravnosti njihovih službenika u odnosu prema ostalim radnicima migrantima (u konkretnom slučaju, u odnosu prema radnicima na koje se primjenjuju odredbe o koordinaciji sustava socijalne sigurnosti) te, s druge strane, kroz zaštitu jednakosti među samim službenicima EU-a, neovisno o njihovu državljanstvu te neovisno o tome u kojoj su državi članici porezni rezidenti. Bez navedenih jamstava, institucijama bi bilo znatno otežano zapošljavanje najkompetentnijeg osoblja na što široj geografskoj osnovi zbog odvraćajućeg učinka diskriminatornog višestrukog poreznog opterećenja od onog radnika zaposlenih kod drugih poslodavaca, a jednako tako bila bi dovedena u pitanje zatupljenost službenika iz različitih država članica zbog nejednakog postupanja prema takvim službenicima u pojedinim državama članicama podrijetla.

Navedeni su razlozi, među ostalima, doveli već u vrijeme samih početaka europske integracije do usvajanja niza propisa kojima se status zaposlenika institucija regulirao na autonoman način. Kao što je to izloženo u dijelu o izvorima službeničkog prava Unije, riječ je o pravilima koja su izravno primjenjiva u državama članicama i koja su one dužne poštovati pri donošenju vlastitih propisa i pri njihovu tumačenju.

Konkretno, uređenje pitanja socijalnog osiguranja službenika institucija EU-a u isključivoj je nadležnosti Unije. Države članice imaju pravo oporezivati prihode svojih poreznih rezidenata koji su zaposlenici europskih institucija poput $\mathrm{W}$. de Lobkowicza, ali pritom moraju poštovati pravo Unije, koje obuhvaća i zaseban korpus pravila koja uređuju status službenika EU-a. Jednako vrijedi i za donošenje (i tumačenje) ostalih propisa koji mogu utjecati na njihov status.

Iako je riječ o problematici koja je slabo poznata široj pravnoj javnosti, valja napomenuti da već postoje prijedlozi hrvatskih propisa koji uzimaju u obzir specifičnost položaju službenika Unije. Primjerice, s obzirom na to da je pristupanjem Republike Hrvatske Europskoj uniji otvorena mogućnost zapošljavanja hrvatskih državljana u institucijama Unije, nadležna hrvatska tijela reagirala su na potrebu za reguliranjem statusa takvih osoba 
radi osiguravanja kontinuiteta njihove socijalne sigurnosti te je, nakon više nacrta, Prijedlogom zakona o prijenosu mirovinskih prava koje je predsjedniku Hrvatskog sabora dostavila Vlada Republike Hrvatske aktom od 13. travnja 2017., predloženo uređenje prijenosa mirovinskih prava iz obveznog mirovinskog osiguranja generacijske solidarnosti i mirovinskih prava iz kapitaliziranog sustava u Republici Hrvatskoj prije zaposlenja u tijelima Europske unije u mirovinsko osiguranje koje se primjenjuje na službenike Unije te prijenos mirovinskih prava iz mirovinskog osiguranja Europske unije u mirovinsko osiguranje Republike Hrvatske nakon prestanka zaposlenja u tijelima Unije. Na sjednici Hrvatskog sabora 30. lipnja 2017. donesen je zaključak da se taj Prijedlog zakona prihvaća.

Dakle, socijalno osiguranje službenika EU-a samo je jedno od pitanja koje je uređeno granom prava koja je još uvijek nedovoljno poznata izvan institucijskih krugova, a koja svakako zaslužuje veću pažnju pravne struke, osobito s obzirom na to da svako prosuđivanje vezano za njihov status nužno zahtijeva poznavanje (i uzimanje u obzir) odredaba službeničkog prava Unije.

\section{Literatura}

Andreone, F. (2015). Hiérarchie des normes et sources du droit de la fonction publique de l'Union européenne [Hijerarhija normi i izvora službeničkog prava Europske unije]. Cabiers du GRASPE, 25, 61-85.

Andreone, F. (2016). Typologie des actes et cadre juridique de la fonction publique de l'Union européenne [Tipologija akata i pravni okvir javne službe Europske unije]. Revue de l'Union européenne, 603, 588-596.

Craig, P. \& de Búrca, G. (2016). EU Law: Text, Cases and Materials (6th ed.).[Pravo EU-a: tekstovi, slučajevi i materijali (6.izdanje)]. Oxford, Ujedinjeno Kraljevstvo: Oxford University Press.

Ćapeta, T. \& Rodin, S. (2011). Osnove prava Europske unije. Zagreb, Hrvatska: Narodne novine.

Dalle-Crode, S. (2008). Le fonctionnaire communautaire - Droits, obligations et régime disciplinaire [Službenik zajednice - Prava, obveze i disciplinski režim]. Bruxelles, Belgija : Bruylant.

Daxkobler, K. (2015). Coordination of social security: the borderline between social security contributions and taxes: case C-623/13 [Koordinacija socijalnog osiguranja: granica između socijalnih doprinosa i poreza: predmet C-623/13]. Ministre de l'économie et des finances v. Gérard de Ruyter, EU:C:2015:123 [Ministar gospodarstva i financija protiv Gerarda de Ruytera]. Maastricht journal of European and comparative law, 22(4), 616-623.

Feugier, J. \& Pradines, M. (2015). La fonction publique européenne en perspective [Europska jarna služba u perspektivi]. Pariz, Francuska: La documentation Française. 
Mijatović, N., Perić, R. \& Lerman, B. (2012). Proračunska pitanja Europske unije: preispitivanje financijske autonomije. Pravni vjesnik, 28(2), 39-57.

O'Leary, S. (2011.), Applying principles of EU social and employment law in EU staff cases [Primjena načela europskog socijalnog i radnog prava u službeničkim sporovima EU-a]. European Law Review, 36(6), 769-797.

Pennings, F. (2014). Cooridnation of Social Security within the EU Context [Koordinacija socijalnog osiguranja u kontekstu EU-a]. U Arellano Ortiz, P., Olivier M. \& Vonk G. (ur.). Social Security and Migrant Workers [Socijalno osiguranje i radnici migranti] (str. 117-132). Alphen a/d Rijn, Nizozemska: Kluwer Law International.

Petrlík, D. (2014). Invocabilité variable des directives dans le domaine de la fonction publique de l'Union européenne [Varijabilna primjenjivost direktiva u području javne službe Europske unije]. Revue des affaires européennes = Law \& European affairs, 4, 803-811.

Pezo, V. (ur.) (2007). Pravni leksikon. Zagreb, Hrvatska: Leksikografski zavod Miroslav Krleža.

Pilorge-Vrancken, J. (2017). Le droit de la fonction publique de l'Union européenne [Službeničko pravo Europske unije]. Bruxelles, Belgija: Bruylant.

Roberts, S. (2010). A short History of Social Security Coordination [Kratka povijest koordinacije socijalnog osiguranja]. U: Jorens,Y. (ur.), 50 years of Social Security Coordination: Past - Present - Future [50 godina koordinacije socijalnog osiguranja: prošlost - sadašnjost - budućnost] (str. 8-28). Luxembourg, Luksemburg: Ured za publikacije Eurospke unije.

Stanković, D. (2016). Novo ustrojstvo Suda Europske unije. Informator: instruktivno-informativni list za ekonomska i pravna pitanja, 6443, 1-2.

Van Raepenbusch, S. (2010). The role of the Court of Justice in the developement of social security law of persons moving within the European Union [Uloga Suda EU-a u razvoju zakona o socijalnom osiguranju osoba koje se kreću unutar Unije ]. U Jorens,Y. (ur.), 50 years of Social Security Coordination: PastPresent-Future [50 godina koordinacije socijalnog osiguranja: prošlost - sadašnjost - budućnost] (str. 29-54). Luxembourg, Luksemburg: Ured za publikacije Eurospke unije.

\section{Propisi}

Konvencija za zaštitu ljudskih prava i temeljnih sloboda, NN MU, 18/97, 6/99, $14 / 02,13 / 03,9 / 05,1 / 06,2 / 10$

Ugovor o Europskoj uniji (pročišćena inačica iz 2016.), Ugovor o funkcioniranju Europske unije (pročišćena inačica iz 2016.), Protokoli, Prilozi Ugovoru o funkcioniranju Europske unije, Izjave priložene Završnom aktu Međuvladine konferencije na kojoj je donesen Ugovor iz Lisabona potpisan 13. prosinca 2007., Tablice ekvivalenata (SL 2016, C 202/01, str. 1)

Povelja o temeljnim pravima Europske unije (2016.) (SL 2016, C 202/02, str. 389). 
Uredba Vijeća (EEZ, Euratom, EZUČ) br. 259/68 od 29. veljače 1968. o Pravilniku o osoblju za dužnosnike [službenike] Europskih zajednica i [uvjetima zaposlenja koji se primjenjuju] na ostale službenike [ostalo osoblje] tih Zajednica i o uspostavi posebnih mjera privremeno primjenjivih na dužnosnike [službenike] Komisije (SL 1968., L 56, str. 1), SL, posebno izdanje na hrvatskom jeziku, poglavlje 1., svezak 6., str. 3.

Uredba Vijeća (EZ) br. 160/2009 od 23. veljače 2009. o izmjeni Uvjeta zaposlenja ostalih službenika [ostalog osoblja] Europskih zajednica (SL 2009., L 55, str. 1.), SL, posebno izdanje na hrvatskom jeziku, poglavlje 1., svezak 17., str. 148.

Uredba Europskog parlamenta i Vijeća (EU, Euratom) br. 1080/2010 od 24. studenoga 2010. o izmjeni Pravilnika o osoblju za dužnosnike [službenike] Europske unije i Uvjeta zaposlenja ostalih službenika [ostalog osoblja] Europske unije, SL L 311, str. 1.

Uredba (EU, Euratom) br. 1023/2013 Europskog parlamenta i Vijeća od 22. listopada 2013. o izmjeni Pravilnika o osoblju za dužnosnike [službenike] Europske unije i Uvjeta zaposlenja ostalih službenika [ostalog osoblja] Europske unije, SL L 287, str. 15.

Uredba Vijeća (EEZ, Euratom, EZUČ) br. 260/68 od 29. veljače 1968. o utvrđivanju uvjeta i postupka za primjenu poreza u korist Europskih zajednica (SL L 56 od 4. ožujka 1968., str 8), SL, posebno izdanje na hrvatskom jeziku, poglavlje 1. sv. 15., str. 12.

Uredba br. 1 o utvrdivanju jezika koji se koriste u Europskoj zajednici za atomsku energiju (SL, 1958., 17, str. 401.), SL, posebno izdanje na hrvatskom jeziku, poglavlje 1., svezak 17., str. 3.

Uredba Vijeća (EEZ) br. 1408/71 od 14. lipnja 1971. o primjeni sustava socijalne sigurnosti na zaposlene osobe i njihove obitelji koji se kreću unutar Zajednice (SL 1971, L 149, str. 2), SL, posebno izdanje na hrvatskom jeziku, poglavlje 5., svezak 5., str. 7.

Uredba Vijeća (EEZ) br. 574/72 od 21. ožujka 1972. o utvrđivanju postupka provedbe Uredbe (EEZ) br. 1408/71 o primjeni sustava socijalne sigurnosti na zaposlene osobe, samozaposlene osobe i članove njihovih obitelji koji se kreću unutar Zajednice (SL1972., L 74, str. 1), SL, posebno izdanje na hrvatskom jeziku, poglavlje 5., svezak 8., str. 3.

Uredba (EZ) br. 883/2004 Europskog parlamenta i Vijeća od 29. travnja 2004. o koordinaciji sustava socijalne sigurnosti (SL 2004., L 166, str. 1), SL, posebno izdanje na hrvatskom jeziku, poglavlje 5., svezak 3., str. 160.

Uredba (EZ) br. 988/2009 Europskog parlamenta i Vijeća od 16. rujna 2009. o izmjeni Uredbe (EZ) br. 883/2004 o koordinaciji sustava socijalne sigurnosti i o utvrđivanju sadržaja njezinih priloga. Tekst značajan za EGP i Švicarsku (SL 2009., L 284, str. 43), SL, posebno izdanje na hrvatskom jeziku, poglavlje 5., svezak 2., str. 213.

Uredba (EZ) br. 987/2009 Europskog parlamenta i Vijeća od 16. rujna 2009. o utvrđivanju postupka provedbe Uredbe (EZ) br. 883/2004 o koordinaciji sustava socijalne sigurnosti. Tekst značajan za EGP i Švicarsku (SL 2009., L 
284, str. 1), SL, posebno izdanje na hrvatskom jeziku, poglavlje 5., svezak 2., str. 171.

Uredba Komisije (EU) br. 1372/2013 od 19. prosinca 2013. o izmjeni Uredbe (EZ) br. 883/2004 Europskog parlamenta i Vijeća o koordinaciji sustava socijalne sigurnosti i Uredbe (EZ) br. 987/2009 Europskog parlamenta i Vijeća o utvrđivanju postupka provedbe Uredbe (EZ) br. 883/2004, SL 2013., L 346, str. 27.

Uredba Komisije (EU) br. 1368/2014 od 17. prosinca 2014. o izmjeni Uredbe (EZ) br. 987/2009 Europskog parlamenta i Vijeća o utvrđivanju postupka provedbe Uredbe (EZ) br. 883/2004 o koordinaciji sustava socijalne sigurnosti i Uredbe Komisije (EU) br. 1372/2013 o izmjeni Uredbe (EZ) br. 883/2004 o koordinaciji sustava socijalne sigurnosti i Uredbe (EZ) br. 987/2009 Europskog parlamenta i Vijeća o utvrđivanju postupka provedbe Uredbe (EZ) br. 883/2004, SL 2014., L 366, str. 15.

Zakon o obvezama i pravima državnih dužnosnika, NN 101/98, 135/98, 105/99, 25/00, 73/00, 30/01, 59/01, 114/01, 153/02, 163/03, 16/04, 30/04, 187/04, $121 / 05,151 / 05,141 / 06,17 / 07,107 / 07,60 / 08,38 / 09,150 / 11,22 / 13,103 /$ $14,03 / 15,93 / 16$

Zakon o plaćama u javnim službama, NN 27/01, 39/09

Zakon o državnim službenicima, NN 92/05, 140/05, 142/06, 77/07, 107/07, 27/08, 34/11, 49/11, 150/11, 34/12, 49/12, 37/13, 38/13, 01/15, 138/15, 61/17

Zakon o službenicima i namještenicima u lokalnoj i područnoj (regionalnoj) samoupravi, NN 86/08, 61/11, 04/18

Zakon o sprječavanju sukoba interesa, NN 26/11, 12/12, 124/12, 48/13, 57/15

Uredba o nazivima radnih mjesta i koeficijentima složenosti poslova u javnim službama, NN 25/13, 72/13,151/13, 09/14, 40/14, 51/14, 77/14, 83/14, ispravak, 87/14, 120/14, 147/14, 151/14, 11/15, 32/15, 38/15, 60/15, 83/15, 1 $12 / 15,122 / 15,10 / 17,39 / 17,40 / 17$, ispravak, 74/17, 122/17, 9/18

Vodič o obvezama dužnosnika i ostalih službenika Europskog parlamenta - kodeks ponašanja (Guide sur les obligations des fonctionnaires et agents du Parlement européen (Code de bonne conduite), SL 2000., C 97., str. 1.

Odluka glavnog tajnika Vijeća/visokog predstavnika za zajedničku vanjsku i sigurnosnu politiku od 25. lipnja 2001. o Kodeksu dobrog upravnog ponašanja Glavnog tajništva Vijeća Europske unije i njegova osoblja u njihovim profesionalnim odnosima s javnošću, (SL 2001., C 189, str. 1), SL, posebno izdanje na hrvatskom jeziku, poglavlje 18., svezak 2., str. 5.

\section{Sudska praksa}

Mišljenje nezavisne odvjetnice Sharpston u predmetu C-623/13 de Ruyter, ECLI:EU:C:2014:2307

Mišljenje nezavisnog odvjetnika Mengozzija u predmetu C-690/15 de Lobkowicz, ECLI:EU:C:2016:926 
Presuda Suda u predmetu 75-63 M.K.H. Hoekstra (née Unger)/Bestuur der Bedrijfsvereniging voor Detailhandel en Ambachten, ECLI:EU:C:1964:19

Presuda Suda u predmetu 137/80 Komisija/Belgija, ECLI:EU:C:1981:237

Presuda Suda u predmetu C-283/81, CILFIT $i$ dr./Ministero della sanitã, ECLI:EU:C:1982:335

Presuda Suda u predmetu 85/85, Komisija/Belgija, ECLI:EU:C:1986:129

Presuda Suda u predmetu Komisija/Francuska, C-57/90, ECLI:EU:C:1992:10

Presuda Suda u predmetu Ferlini C-411/98, ECLI:EU:C:2000:530

Presuda Suda u predmetu C-623/13 de Ruyter, ECLI:EU:C:2015:123

Presuda Suda u predmetu C-690/15 de Lobkowicz, ECLI:EU:C:2017:355

Presuda Službeničkog suda u predmetu F-65/07 Aayban i dr./Europski parlament, ECLI:EU:F:2009:43

Presuda Službeničkog suda u spojenim predmetima F-137/07 i F-8/08 Adjemian $i$ dr./ Komisija Europskih zajednica, ECLI:EU:F:2009:51 


\section{SOCIAL CONTRIBUTIONS OF EUROPEAN UNION CIVIL SERVANTS}

\section{Summary}

The single member state social legislation principle is of fundamental importance when it comes to the coordination of social security schemes in the European Union. It has led to an extensive database of cases at the Court of Justice of the European Union (CJEU) and numerous research papers have investigated the conditions under which it was applied. On the other hand, the EU employs approximately 40,000 people who are subject to the joint social security scheme of EU institutions, and to whom the regulations on the coordination of social security schemes do not apply. Regulations governing the legal status of EU civil servants have been in place since the onset of European integration processes; however, the specifics of their legal status are relatively little known, even in the founding member states. This became obvious in the recent CJEU judgment in the case of Wenceslas de Lobkowicz. In this case the CJEU looked at the question of the applicability of national regulations which impose an obligation on the tax residents of a particular member state, with compulsory affiliation to the joint social security scheme of EU institutions, to contribute to the funding of the social security scheme of that same member state. This paper describes the rules of coordination of social security schemes in the $E U$ and provides an analysis of the CJEU's argumentation in their judgment in the Lobkowicz case. The paper also provides a comprehensive overview of the regulations governing the legal status of EU civil servants and considers the implications these regulations have on the legal systems of member states. Although the regulation of social policy issues in the EU falls within the competence of each member state, the regulations governing the status of EU civil servants apply directly in member states. This means that any judgment regarding their status requires the knowledge and consideration of this branch of law.

Keywords: EU civil servants, EU officials, compulsory affiliation to the joint social security scheme of EU institutions, contributing to the funding of social security of a member state, single member state social legislation principle 